\title{
ETIKA DAN PROFESI GURU SD DI TENGAH PERKEMBANGAN ZAMAN
}

\author{
Bayu Purbha Sakti \\ Universitas Widya Dharma \\ bayumor@gmail.com
}

\begin{abstract}
ABSTRAK
Beberapa kasus yang menimpa Dasrul dan saifudin telah mencoreng nama guru. Kejadian tesebut menjadi koreksi untuk merevisi etika dan profesi guru. Makalah ini membahas aturan yang harus ditegakkan kembali supaya guru lebih memahami etika dan profesi. Etika dan profesi guru sekolah dasar harus disesuaikan dengan peraturan yang telah ditetapkan pemerintah. Guru harus mematuhi kode etik guru Indonesia dan tugas profesi yang telah tercantum dalam Undang-undang Republik Indonesia. Guru SD wajib memiliki etika dan menjalankan profesinya dengan baik dengan memiliki pemahaman dalam kurikulum, peraturan, dan kondisi terkini sekitar untuk mewujudkan proses belajar mengajar yang baik.
\end{abstract}

Kata kunci : etika, profesi guru 


\section{PENDAHULUAN}

Perkembangan zaman telah menimbulkan perubahan bagi dunia pendidikan. Guru pada zaman sekarang dituntut untuk lebih memiliki etika yang lebih baik. Profesi yang dijalani oleh seorang guru adalah sebuah profesi yang mulia. Guru dituntut untuk memiliki karakter yang baik karena masyarakat sudah mulai menganggap pendidikan yang memiliki layanan mendidik yang baik akan dipilih. Guru pada zaman sekarang sudah selayaknya untuk memiliki kompetensi kepribadian, sosial, paedagogik, dan profesional.

Guru yang memiliki kepribadian yang baik tentunya akan disayangi oleh para siswa. Setiap siswa mengharapkan guru mereka dapat menjadi contoh atau model yang baik. Oleh karena itu tingkah laku guru harus sesuai dengan norma-norma yang dianut oleh masyarakat, bangsa dan negara. Karena nilai-nilai dasar negara dan bangsa Indonesia adalah Pancasila, maka tingkah laku guru harus selalu memahami nilai-nilai Pancasila.

Guru yang memiliki kemampuan berkomunikasi dengan orang tua siswa dengan baik tentunya akan menyebabkan hubungan sosial yang baik di masyarakat. Seorang guru diharapkan dapat berperan aktif dalam pembangunan di masyarakat dalam segala bidang yang sedang dilakukan. Seorang guru diharapkan dapat membantu kawannya yang memerlukan bantuan dalam mengembangkan kemampuannya. Bantuan dapat secara langsung melalui pertemuan-pertemuan resmi maupun pertemuan insidental.
Guru yang mendidik siswa dengan benar tentunya akan menyebabkan asumsi pada masyarakat bahwa anak mereka layak menjadi siswa pada sekolah yang memiliki kualifikasi guru yang berkompeten. Siswa yang memiliki karakter yang baik adalah cerminan dari karakter seorang guru. Siswa yang berada dalam pengawasan dan pembinaan guru akan menyebabkan siswa taat, patuh, dan tertib dalam menjalani kegiatan pembelajaran di sekolah.

Seorang guru tidak hanya sebagai pendidik dan pengajar, tetapi juga sebagai administrator pada bidang pendidikan dan pengajaran. Oleh karena itu seorang guru dituntut bekerja secara administrasi dengan teratur. Segala pelaksanaan dalam kaitannya proses belajar mengajar perlu diadministrasikan secara baik. Sebab administrasi yang dikerjakan seperti membuat rencana mengajar, mencatat hasil belajar dan sebagainya merupakan dokumen yang berharga bahwa ia telah melaksanakan tugasnya dengan baik. Tumbuh kembang siswa di sekolah menjadi tanggung jawab guru sehingga siswa akan mencapai kematangannya secara emosional, fisik, psikis, intelejensi, kepribadian, dan sosial.

Namun ada beberapa kejadian yang mencoreng nama baik guru pada tahun 2016 ini. Peristiwa yang terjadi di Majalengka Jawa barat telah menyebabkan polemik di kalangan masyarakat. Peristiwa yang menimpa seorang guru yang bernama Aop Saopudin telah mengarah ke jalur hukum. Peristiwanya itu sendiri berlangsung dari kejadian ketika Aop Saopudin mendisiplinkan empat 
orang siswa berambut gondrong dengan mencukur rambut ke-4 anak tersebut pada Maret 2012. Salah seorang siswa dan orangtuanya tidak terima dan melabrak Aop dengan memukul dan mencukur balik gurunya

(http://www.sumeks.co.id/index.php/m etropolis/budaya-opini/19159-sinyalkemenangan-guru).

Aop Saopudin didakwa pasal berlapis yakni pasal 77 a UU Perlindungan anak tentang perbuatan diskriminasi terhadap anak; pasal 80 ayat 1 UU Perlindungan Anak; pasal 35 ayat 1 KUHP tentang perbuatan tidak menyenangkan. Aop sudah dibela oleh demo guru-guru tetapi pihak polisi dan jaksa tetap melimpahkan kasusnya ke pengadilan. Hal tersebut tentu saja menjadi koreksi kita semua dalam hal memahami dunia pendidikan. Hubungan antara guru dengan masyarakat tentunya harus diperbaiki untuk tidak memunculkan kasus Aop di daerah lain.

Kejadian yang mencoreng nama baik guru pada tahun 2016 ini adalah peristiwa yang dialami seorang guru yang bernama Dasrul. Dirjen Guru dan Tenaga Kependidikan (GTK) Kemdikbud, Sumarna Surapranata menyesalkan semakin memburuknya hubungan antara orang tua murid dan guru ini. Peristiwa yang terjadi di Makasar ini telah menyebabkan ketegangan di kalangan masyarakat. Menurut Pranata, ketegangan yang berakhir kekerasan bahkan tindakan hukum merupakan buah dari saling melunturnya kepercayaan di antara guru dan orang tua. "Kepercayaan orang tua ke sekolah sudah luntur, begitu juga kepercayaan guru ke orang tua," ungkap Pranata, di Jakarta, akhir pekan kemarin (http://www.koran-

jakarta.com/perkuat-komunikasi-guruorang-tua/).

Beberapa kejadian tersebut sudah menjadi berita di masyarakat karena peran teknologi sekarang memang lebih terjangkau. Oleh karena itu ada beberapa pendapat dari kalangan politik dalam menyelesaikan beberapa permasalahan yang dialami guru. Fadli Zon selaku Wakil Ketua DPR mendorong dibentuknya dewan kehormatan guru untuk melindungi profesi guru dari masalah etik ataupun tindakan yang merugikan profesi guru. Fadli Zon mengatakan kalau guru tidak dihormati bahkan mengalami kriminalisasi maka akan merusak sistem pendidikan Indonesia.

Abdul Fikri Faqih selaku Wakil Ketua Komisi X DPR mengatakan perlu dihidupkan kembali dewan kehormatan guru sebagai pelaksanaan UU nomor 14 tahun 2005 tentang Guru dan Dosen. Dewan tersebut menurut dia, sebagai lembaga yang melindungi profesi guru. Abdul Fikri Faqih menilai selama ini pemangku kepentingan pendidikan dari guru/dosen, siswa, penyelenggara pendidikan hanya konsentrasi kepada kurikulum, operasional dan sarana-prasarana. Namun menurut dia, penegakan aturan, perlindungan dan penegak etika luput dari perhatian (http://www.antaranews.com/berita/5 78248/pemimpin-dpr-dorongpembentukan-dewan-kehormatanguru).

Tugas yang harus dihadapi guru lainnya adalah pemberian materi 
pendidikan karakter dan budi pekerti dalam kegiatan pembelajaran di tingkat SD dan SMP. Muhadjir Effendy selaku Menteri Pendidikan dan Kebudayaan (Mendikbud) mengatakan pendidikan karakter harus mendominasi pendidikan dasar atau untuk tingkat Sekolah Dasar (SD) dan Sekolah Menengah Pertama (SMP). Muhadjir Effendy mengatakan pendidikan karakter harus mendominasi pendidikan dasar, untuk tingkat SD pendidikan karakter dan budi pekerti itu proporsinya 70 persen dan untuk tingkat SMP sebanyak 60 persen. Untuk tingkat pendidikan dasar, lanjut dia, pendidikan karakter itu mutlak diberikan oleh para guru (http://banjarmasin.tribunnews.com/20 16/08/22/masalah-pendidikan-dasarini-pendapat-mendikbud).

Berbagai permasalahan yang dialami guru telah meramaikan pendapat dari berbagai kalangan. Oleh karena itu etika dan profesi yang baik harus ditunjukkan guru dari berbagai jenjang pendidikan. Guru sekolah dasar memiliki peranan penting demi terciptanya kondisi siswa yang lebih baik. Siswa sekolah dasar yang terdidik dengan baik akan menciptakan hasil didikan yang menjadi masukan yang baik menuju jenjang sekolah menengah pertama.

\section{PERMASALAHAN}

Berdasarkan keterangan yang dijelaskan pada bagian pendahuluan di atas, maka terdapat permasalahan yang dipertanyakan antara lain sebagai berikut:

1. Bagaimana etika yang harus dilakukan guru sekolah dasar dalam menghadapi perkembangan zaman?
2. Bagaimana profesi yang harus dilakukan guru sekolah dasar dalam menghadapi perkembangan zaman?

\section{PEMBAHASAN}

\section{A. Etika guru}

Dalam kamus besar bahasa Indonesia, etika adalah ilmu tentang apa yg baik dan apa yg buruk dan tentang hak dan kewajiban moral (akhlak). Etika berasal dari bahasa yunani yaitu Etos yang berarti adat kebiasaan, cara berfikir, akhlak, sikap, watak, cara bertindak. Kemudian etika diturunkan ke kata Ethich (Inggris) dan etika (Indonesia). Etika menyelidiki suatu perbuatan mana yang baik dan mana yang buruk.

Etika yang dijalankan guru harus diimbangi dengan wawasan pengetahuan yang menyeluruh. Orang tertentu yang terpilih menjadi seorang guru tentu memahami kode etik guru. Kode etik tersebut tidak hanya dibaca dan dipahami saja tetapi diterapkan dan dipraktikkan. Seorang guru menerapkan kode etik tidak hanya di lingkungan sekolah saja melainkan di lingkungan keluarga, masyarakat, bangsa, dan negara.

Guru harus bisa memahami dan menerapkan kode etik guru sesuai hasil keputusan Kongres XXI Persatuan Guru Republik Indonesia Nomor VI /Kongres/XXI/PGRI/2013. Hasil dari kongres tersebut adalah kewajiban guru antara lain;

1) Kewajiban Umum

2) Kewajiban Guru Terhadap Peserta Didik

3) Kewajiban Guru terhadap Orangtua/Wali Peserta Didik 
4) Kewajiban Guru terhadap Masyarakat

5) Kewajiban Guru terhadap Teman Sejawat

6) Kewajiban Guru terhadap Profesi

7) Kewajiban Guru terhadap Organisasi Profesi

8) Kewajiban Guru terhadap Pemerintah

Guru memiliki kewajiban menjunjung tinggi, menghayati, dan mengamalkan sumpah/ janji guru. Guru harus melaksanakan tugas utama mendidik, mengajar, membimbing, mengarahkan, melatih, menilai dan mengevaluasi peserta didik untuk mewujudkan tujuan pendidikan nasional.

Guru memiliki kewajiban mengembangkan suasana pembelajaran yang aktif, kreatif, efektif dan menyenangkan. Guru harus menghormati martabat dan hak-hak serta memperlakukan peserta didik secara adil dan objektif. Guru memiliki kewajiban menghormati hak orang tua/wali peserta didik untuk berkonsultasi dan memberikan informasi secara jujur dan objektif mengenai kondisi dan perkembangan belajar peserta didik. Guru harus membina hubungan kerja sama dengan orang tua/wali peserta didik dalam melaksanakan proses pendidikan untuk peningkatan mutu pendidikan.

Guru memiliki kewajiban menjalin komunikasi yang efektif dan kerjasama yang harmonis dengan masyarakat untuk memajukan dan mengembangkan pendidikan. Guru harus mengakomodasi aspirasi dan keinginan masyarakat dalam pengembangan dan peningkatan kualitas pendidikan. Guru harus Bersikap responsif terhadap perubahan yang terjadi dalam masyarakat dengan mengindahkan norma dan sistem nilai yang berlaku. Guru memiliki kewajiban membangun suasana kekeluargaan, solidaritas, dan saling menghormati antarteman sejawat di dalam maupun di luar satuan pendidikan. Guru harus saling berbagi ilmu pengetahuan, teknologi, seni, keterampilan, dan pengalaman, serta saling memotivasi untuk meningkatkan profesionalitas dan martabat guru. Guru harus menjaga kehormatan dan rahasia pribadi teman sejawat.

Guru memiliki kewajiban mengembangkan profesionalisme secara berkelanjutan sesuai kemajuan ilmu pengetahuan dan teknologi untuk meningkatkan mutu pendidikan. Guru harus melakukan tindakan dan/atau mengeluarkan pendapat yang tidak merendahkan martabat profesi.

Guru memiliki kewajiban menaati peraturan dan berperan aktif dalam melaksanakan program organisasi profesi. Guru harus mengembangkan dan memajukan organisasi profesi. Guru harus mengembangkan organisasi profesi untuk menjadi pusat peningkatan profesionalitas guru dan pusat informasi tentang pengembangan pendidikan.

Guru memiliki kewajiban berperan serta menjaga persatuan dan kesatuan dalam kehidupan berbangsa dan bernegara dalam wadah NKRI berdasarkan Pancasila dan UUD 1945. Guru harus berperan serta dalam melaksanakan program pembangunan pendidikan. Guru harus melaksanakan ketentuan yang 
ditetapkan pemerintah.

\section{B. Profesi guru}

Dalam kamus besar bahasa Indonesia, profesi adalah bidang pekerjaan yg dilandasi pendidikan keahlian (keterampilan, kejuruan, dsb) tertentu. Profesi adalah kata serapan dari sebuah kata dalam bahasa Inggris "Profess", yang bermakna Janji untuk memenuhi kewajiban melakukan suatu tugas khusus secara tetap/permanen. Profesi adalah pekerjaan yang dilakukan sebagai kegiatan pokok untuk menghasilkan nafkah hidup dan yang mengandalkan suatu keahlian.Profesi sebagai pekerjaan yang menuntut keahlian tertentu serta memiliki etika khusus untuk jabatan tersebut serta pelayanan baku terhadap masyarakat.

Pengertian guru sesuai dengan Undang-undang Republik Indonesia Nomor 14 tahun 2005 adalah pendidik profesional dengan tugas utama mendidik, mengajar, membimbing, mengarahkan, melatih, menilai, dan mengevalusi peserta didik pada pendidikan anak usia dini jalur pendidikan formal, pendidikan dasar dan pendidikan menengah. Setiap orang dapat menjadi guru asalkan telah mengalami jenjang pendidikan tertentu ditambah dengan sedikit pengalaman mengajar. Karena itu seorang dapat saja mengajar di TK sampai dengan perguruan tinggi, jika dia telah mengalami pendidikan tersebut dan telah memiliki pengalaman mengajar di kelas. Selain dan itu, ada beberapa bukti bahwa pendidikan dapat saja berhasil walaupun si pengajarnya tidak pernah belajar ilmu pendidikan dan keguruan.
Profesi sebagai guru menjadikan manusia lebih bermartabat. Hal itu juga harus dilakukan sesuai dengan peraturan yang berlaku dan diterapkan dengan baik supaya tercipta guru yang dapat meningkatkan kualitas pendidikan di Negara Kesatuan Republik Indonesia. Profesi guru telah diatur dalam Undang-undang Republik Indonesia Nomor 14 tahun 2005 tentang guru dan dosen dengan teratur. Sesuai pasal 20 Undangundang Republik Indonesia Nomor 14 tahun 2005, guru melaksanakan tugas keprofesionalan dengan kewajiban antara lain;

1) Merencanakan pembelajaran, melaksanakan proses pembelajaran yang bermutu, serta menilai dan mengevaluasi hasil pembelajaran;

2) Meningkatkan dan mengembangkan kualifikasi akadernik dan kompetensi secara berkelanjutan sejalan dengan perkembangan ilmu pengetahuan, teknologi, dan seni;

Bertindak objektif dan tidak diskriminatif atas dasar pertimbangan jenis kelamin, agama, suku, ras, dan kondisi fisik tertentu, atau latar belakang keluarga, dan status sosial ekonomi peserta didik dalam pembelajaran;

3) Menjunjung tinggi peraturan perundang-undangan, hukum, dan kode etik guru, serta nilainilai agama dan etika; dan

4) Memelihara dan memupuk persatuan dan kesatuan bangsa.

Peran guru sangat vital dalam melaksanakan kegiatan pembelajaran. Oleh karena itu guru 
harus memahami dan menerapkan 4 kompetensi yang sangat diharapakan demi meningkatkan kualitas pendidikan. Kompetensi tersebut tertuang dalam Undang-Undang Dosen dan Guru, yakni:

1) Kompetensi pedagogik adalah kemampuan mengelola pembelajaran peserta didik,

2) Kompetensi kepribadian adalah kemampuan kepribadian yang mantap, berakhlak mulia, arif, dan berwibawa serta menjadi teladan peserta didik,

3) Kompetensi profesional adalah kamampuan penguasaan materi pelajaran luas mendalam,

4) Kompetensi sosial adalah kemampuan guru untuk berkomunikasi dan berinteraksi secara efektif dan efisien dengan peserta didik, sesama guru, orang tua/wali peserta didik, dan masyarakat sekitar.

Perguruan tinggi kependidikan telah diberi tugas oleh Pemerintah Indonesia untuk menyelenggarakan program pengadaan guru pada pendidikan anak usia dini jalur pendidikan formal, pendidikan dasar, dan/atau pendidikan menengah, serta untuk menyelenggarakan dan mengembangkan ilmu kependidikan dan nonkependidikan. Pendidikan profesi sesuai Peraturan Menteri Pendidikan dan Kebudayaan Republik Indonesia Nomor 87 Tahun 2013 tentang Program Pendidikan Profesi Guru Prajabatan adalah pendidikan tinggi setelah program sarjana yang mempersiapkan peserta didik untuk memiliki pekerjaan dengan persyaratan keahlian khusus. Dengan adanya peraturan tentang kriteria lulusan guru maka diharapakan sumber daya manusia yang dihasilkan benar-benar sesuai etika dan profesi guru yang baik.

Dalam Peraturan Menteri

Pendidikan Nasional Nomor 16

Tahun 2007 tanggal 4 Mei 2007

disebutkan bahwa guru pada SD/MI

harus memiliki kualifikasi akademik pendidikan minimum Diploma

Empat (D-IV) atau Sarjana (S1) dalam bidang pendidikan SD/MI (D-IV/S1 PGSD/PGMI) atau psikologi yang diperoleh dari program studi yang terakreditasi. Dari penjelasan tersebut diharapkan guru sekolah dasar memiliki fungsi dan keahlian dalam menangani anak usia sekolah dasar.

Anak usia sekolah dasar yang berusia 7 sampai dengan 11 tahun berada pada tahapan operasional konkret menurut Piaget (2008). Anak usia sekolah dasar sudah mampu untuk berpikir secara benar dan logis. Anak usia sekolah dasar dapat menyusun dan mengurutkan benda berdasarkan ukuran, volume, dan berat. Mereka juga dapat membandingkan dari benda yang sudah diurutkan tersebut jika ditanya mana yang besar dan kecil. Anak perempuan tumbuh lebih pendek daripada anak laki-laki sebelum usia anak perempuan menginjak 9 tahun. Setelah usia anak perempuan menginjak 11 tahun maka anak tersebut tumbuh dan berkem-bang lebih pesat bila dibandingkan anak laki-laki. Tulang dan otot anak perempuan dan anak laki-laki mulai berkembang pesat pada usia 10 tahun walaupun perkembangan anak lakilaki tertinggal 12 bulan. Kemampuan motorik mereka juga telah berkembang seperti keseimbangan, berlari, melompat, dan melempar. 
Hal tersebut dapat mendukung kegiatan pembelajaran yang diselingi aktivitas permainan yang dapat dimodifikasi guru sekolah dasar.

Tanda-tanda pendidikan berkualitas tinggi di sekolah dasar menurut Berk, (2012: 433) adalah kecukupan ukuran kelas, kelayakan lingkungan fisik, kesesuaian kurikulum, kebutuhan aktivitas harian, adanya interaksi dari guru, adanya evaluasi perkembangan, dan adanya hubungan dari orangtua yang berguna bagi anak usia sekolah dasar untuk belajar di sekolah. Terselenggaranya berbagai hal tersebut dapat menciptakan solusi pembelajaran bagi siswa sekolah dasar untuk berprestasi baik di lingkungan keluarga, sekolah, maupun masyarakat.

\section{KESIMPULAN}

Guru sekolah dasar harus memenuhi standar persyaratan secara administrasi, teknik, psikis dan fisik yang merupakan prasyarat terpenting bagi seseorang untuk menjadi guru. Guru SD bertanggung jawab untuk membawa peserta didik pada suatu kedewasaan atau tingkat kematangan tertentu, dan yang harus digaris bawahi bahwa peserta didik usia sekolah dasar merupakan cikal bakal atau pondasi yang akan dibangun kelak di kemudian hari. Tanggung jawab guru SD bukan hanya mengajar melainkan mendidik dan sekaligus berperan sebagai pembimbng yang memberikan pengarahan dan menuntun peserta didik dalam belajar. Dalam proses pembelajaran yang menyeluruh baik di dalam maupun di luar sekolah maka guru SD wajib memiliki etika dan menjalankan profesinya dengan baik dengan memiliki pemahaman dalam kurikulum, peraturan, dan kondisi terkini dengan lingkungan sekitar untuk mewujudkan proses belajar mengajar yang baik.

\section{DAFTAR PUSTAKA}

Anonim. (2016). Perkuat komunikasi guru dengan orang tua.

http://www.koranjakarta.com/perkuatkomunikasi-guruorang-tua.

Anonim. (2003). Kamus Umum Bahasa Indonesia. Jakarta: Balai Pustaka.

Berk, L.E. (2012). Development through the lifespan. (Terjemahan

Daryatno). Boston: Pearson Education Inc. (Buku asli diterbitkan tahun 2010).

Budilaksono, I. (2016). Pemimpin DPR dorong pembentukan dewan kehormatan guru. http://www.antaranew s.com/berita/578248/p emimpin-dpr-dorongpembentukan-dewankehormatan-guru.

Depdikbud. (2013). Peraturan Menteri Pendidikan dan Kebudayaan Republik Indonesia Nomor 87 Tahun 2013 tentang Program 
Pendidikan Profesi

Guru Prajabatan.

Jakarta.

Depdiknas. (2007). Peraturan

Menteri Pendidikan

Nasional No. 16

Tahun 2007 tentang

Standar Kualifikasi

dan Kompetensi

Guru. Jakarta.

Julheri.

(2016).

http://www.sumeks.co

.id/index.php/metropo

lis/budaya-

opini/19159-sinyal-

kemenangan-guru.

Piaget. (2008). Piaget's theory of

cognitive development. http://en.wikipedia.

org/wiki/Piaget\%27s_t

heory_of_cognitive_de velopment.html.

Sulistiyo. (2013). Kode Etik Guru

Indonesia. Keputusan

Kongres XXI

Persatuan Guru

Republik Indonesia

Nomor : VI

/Kongres/XXI/PGRI/2

013. Jakarta.

Trio, D. (2016). Masalah Pendidikan

Dasar, ini pendapat Mendikbud.

http://banjarmasin.trib

unnews.com/2016/08/

22/masalah-

pendidikan-dasar-ini-

pendapat-mendikbud. 